University of Nebraska - Lincoln

DigitalCommons@University of Nebraska - Lincoln

\title{
Boll Weevil (Coleoptera: Curculionidae) Survival Through the Seed Cotton Cleaning Process in the Cotton Gin
}

Thomas W. Sappington

USDA-ARS, tsapping@iastate.edu

Alan D. Brashears

USDA-ARS

Megha N. Parajulee

Texas Agricultural Experiment Station

Stanley C. Carroll

Texas Agricultural Experiment Station

Mark D. Arnold

Texas Agricultural Experiment Station

See next page for additional authors

Follow this and additional works at: https://digitalcommons.unl.edu/usdaarsfacpub

Part of the Agricultural Science Commons

Sappington, Thomas W.; Brashears, Alan D.; Parajulee, Megha N.; Carroll, Stanley C.; Arnold, Mark D.; and Baker, Roy V., "Boll Weevil (Coleoptera: Curculionidae) Survival Through the Seed Cotton Cleaning Process in the Cotton Gin" (2004). Publications from USDA-ARS / UNL Faculty. 726.

https://digitalcommons.unl.edu/usdaarsfacpub/726

This Article is brought to you for free and open access by the U.S. Department of Agriculture: Agricultural Research Service, Lincoln, Nebraska at DigitalCommons@University of Nebraska - Lincoln. It has been accepted for inclusion in Publications from USDA-ARS / UNL Faculty by an authorized administrator of DigitalCommons@University of Nebraska - Lincoln. 
Authors

Thomas W. Sappington, Alan D. Brashears, Megha N. Parajulee, Stanley C. Carroll, Mark D. Arnold, and Roy V. Baker 


\title{
Boll Weevil (Coleoptera: Curculionidae) Survival Through the Seed Cotton Cleaning Process in the Cotton Gin
}

\author{
THOMAS W. SAPPINGTON, ${ }^{1}$ ALAN D. BRASHEARS, ${ }^{2}$ MEGHA N. PARAJULEE, ${ }^{3}$ \\ STANLEY C. CARROLL,${ }^{3}$ MARK D. ARNOLD,${ }^{3}$ AND ROY V. BAKER ${ }^{2}$ \\ USDA-Agricultural Research Service, Kika de la Garza Agricultural Research Center, 2314 E. Highway 83, \\ Weslaco, TX 78596
}

J. Econ. Entomol. 97(4): 1323-1329 (2004)

\begin{abstract}
There is concern that gins located in boll weevil, Anthonomus grandis grandis Boheman, eradication zones may become points of reintroduction when they process cotton grown in a neighboring infested area. We estimated boll weevil survival through two typical machine sequences used in commercial cotton gins to clean and dry the seed cotton in advance of the gin stand, as well as separately through two incline cylinder cleaners or one or two tower dryers operating at different temperatures. Large numbers of laboratory-reared adult boll weevils were marked with fluorescent powder, fed into the test system, and recovered with the assistance of blacklights. We found no evidence of survival through the seed cotton cleaning systems even when the dryers were not heated, or when passed separately through the two incline cleaners alone. Upper confidence limits (95\%) were calculated for the observed zero recoveries based on sample size and the binomial distribution, and these represent the statistical worst-case (i.e., highest) survival potential. Survival through heated tower dryers declined rapidly to zero at higher temperatures, especially when two dryers were running. Although we conclude that the potential for survival of weevils in the seed cotton to the gin stand is zero or close to zero, a small percentage of live weevils was recovered in the green boll/rock trap, which may represent the greatest threat of reintroduction at the gin. Escape of live weevils with the gin trash is also possible, and studies addressing this issue will be presented elsewhere.
\end{abstract}

KEY WORDS Anthonomus grandis, boll weevil, cotton gin, seed cotton cleaning, eradication

EFFORTS ARE UNDERWAY IN the central Cotton Belt to eradicate the boll weevil, Anthonomus grandis grandis Boheman, historically the most devastating pest of cotton, Gossypium spp., since it invaded this country from Mexico about a century ago. Eradication programs are very expensive, costing a total of $\$ 122.9$ million in 2002 nationwide (Williams 2003), and reintroductions of weevils to eradicated or nearly eradicated zones through human-mediated transport are of great concern. Blocks of counties within a state enter an eradication program after the passage of a referendum, so zones become active in different years between and within states. Thus, it is not uncommon for a zone that is advanced in the eradication process to share one or more borders with a zone that still harbors high populations of weevils.

\footnotetext{
Mention of trade names or commercial products in this article is solely for the purpose of providing specific information and does not imply recommendation or endorsement by the U.S. Department of Agriculture.

${ }^{1}$ Corresponding author. Current address: USDA-ARS-CICGRU, Genetics Laboratory, Iowa State University, Ames, IA 50011 (e-mail: tsapping@iastate.edu).

${ }^{2}$ USDA-ARS-CPPRU, Rt. 3 Box 215, Lubbock, TX 79401-9750.

${ }^{3}$ Texas Agricultural Experiment Station, Agriculture Research and Extension Center at Lubbock, Rt. 3 Box 219, Lubbock, TX 79403.
}

The question has arisen whether a gin located in a boll weevil-suppressed area that processes cotton grown in a neighboring infested zone is likely to serve as a source of boll weevil reintroductions. We have found that in boll weevil-infested regions, boll weevils are usually present in defoliated cotton fields and can be expected to be harvested with the cotton and packed alive into cotton modules (Sappington et al. 2004). Most of these boll weevils survive at least $1 \mathrm{wk}$ inside the module, and so can be expected to be fed alive into the cotton gin. We began a series of experiments to determine the probability of boll weevil survival through the various ginning subprocesses and thus to determine the likelihood of a boll weevil escaping alive into the environment via the various products of the gin, including gin trash, cottonseed, motes, and baled lint.

The primary purpose of the cotton gin is to separate seed from lint, and optimal operation of the gin stand requires the prior removal of large trash objects such as burs and sticks (Baker et al. 1994a). In addition, the quality and commercial value of the lint is affected greatly by contaminating foreign material, so much emphasis is placed on cleaning the lint of small pieces of leaves and other debris both before and after pro- 
cessing through the gin stand (Anthony 1994, Baker et al. 1994a, Siddaiah et al. 2002). Optimal cleaning in turn depends on low moisture content of the seed cotton, and one or two tower dryers are often integrated with the cleaning machinery to heat and dry the seed cotton (Hughs et al. 1994, Nelson and Turner 2003). In this article, we report the results of studies on boll weevil survival through two typical sequences of seed cotton cleaning and drying machinery. The results will help guide the drafting of regulations involving interzonal ginning of harvested cotton.

\section{Materials and Methods}

Experiments were conducted using the full-scale research gin at the USDA-ARS Cotton Ginning Research Laboratory in Lubbock, TX. Experiments were conducted using adult boll weevils reared at the USDA-APHIS Mission Plant Protection Center, Mission, TX. The experiments consisted of introducing a specified number of adults to a seed cotton cleaning process and determining survival. Both free adults and adults encapsulated in simulated pupal cells were tested.

A boll weevil pupal cell is a brittle chamber of tightly packed larval frass, and such cells have been found inside cotton modules (Sappington et al. 2004). Because it was not possible to collect large numbers of natural pupal cells, we instead encased adult boll weevils in empty gelatin capsules (No. 4 size, T.U.B. Enterprises, Almonte, Ontario, Canada), which were baked and dehydrated to make them as brittle as possible in an effort to more accurately simulate the natural pupal cells (Sappington et al. 2004). These simulated pupal cells clearly differ from natural pupal cells in many respects, but they afford greater protection to the enclosed adults than the natural cells, and so estimates of mortality will be conservative. In all experiments, both capsules and boll weevils were marked with fluorescent powder (Switzer Brothers Inc., Cleveland, $\mathrm{OH}$ ) to facilitate recovery from the seed cotton under blacklights.

Boll Weevil Survival through Minimum and Enhanced Seed Cotton Cleaning Processes. For each replication of each treatment, 1000 free adult boll weevils were marked with fluorescent powder, briefly chilled to prevent flight, and distributed as evenly as possible into $45.4-\mathrm{kg}$ lots of stripper-harvested seed cotton spread along a 12.2-m conveyor belt. The fluorescent powder is very persistent, so it was assumed that all weevils remained well-marked throughout the experiment. The boll weevil-treated cotton was mixed thoroughly in a bin and fed into the laboratory's seed cotton cleaning system at the suction telescope. The floor around the conveyor belt and the inside of the bin were searched thoroughly for boll weevils that did not enter the system. In addition, a box was placed at the outlet of the green-boll (or rock) trap to recover boll weevils removed by this device before entry into the cleaning machinery. The cleaned seed cotton was collected at the gin stand feeder apron after the required amounts of cleaning and extraction.
Ten $\approx 1000$-g samples were randomly collected from different physical locations in the receiving bin for each cleaned seed-cotton lot, weighed, and manually evaluated under blacklights for the presence of boll weevils.

Two seed cotton cleaning levels were tested, "minimum" and "enhanced," and each was replicated five times. The machinery sequence for the minimum level of cleaning, which is typically used for pickerharvested cotton (Anthony et al. 1994, Baker et al. 1994a), was green-boll/rock trap, feed control, tower dryer (no heat), incline cylinder cleaner, stick machine, tower dryer (no heat), incline cylinder cleaner, and extractor-feeder. Stripper-harvested cotton contains much more foreign matter than picker-harvested cotton (Baker et al. 1994a), and gins usually use more cleaning steps for the former. Thus, we tested a typical machine sequence for an enhanced level of cleaning (Baker 1994, Baker et al. 1994a): green-boll trap, feed control, tower dryer (no heat), incline cylinder cleaner, combination bur and stick machine, tower dryer (no heat), incline cylinder cleaner, stick machine, and extractor-feeder. The green-boll/rock trap was a hopper-type (Laird et al. 1994) and was followed by an air line cleaner. Both incline cleaners were gravity fed.

A similar experiment was conducted separately using marked encapsulated boll weevils. However, only 100 were introduced per replication, and the experiment was replicated three times each for the minimum and enhanced cleaning treatments.

Boll Weevil Survival through Incline Cylinder Cleaners. To determine the independent effect of the incline cleaners on boll weevil survival in the seed cotton, 500 free adults and 100 encapsulated adult boll weevils per replication were marked with different colors of fluorescent powder, and fed together into the laboratory's two incline cleaners at the suction telescope by using the methodology described above. The boll weevil-treated seed cotton was exposed to the green-boll trap and also was passed through the unheated dryers, each of which emptied into one of the incline cleaners. The other types of cleaning machinery were bypassed. The cleaned seed cotton was collected at the gin stand feeder apron and subsampled for inspection under blacklights as described above. The experiment was replicated five times.

Boll Weevil Survival through Tower Dryers. In both previous experiments, boll weevils were carried with the seed-cotton through two tower dryers, but neither was heated. Although a dryer is not a cleaning device per se, it does remove some foreign matter, and it was anticipated that it could be a source of heatinduced mortality among boll weevils as well. Commercial gins generally operate one or two dryers, with temperatures adjusted automatically depending on the moisture content of the seed cotton (Hughs et al. 1994). Therefore, we tested survival of boll weevils passing through one or two tower dryers heated to varying temperatures.

Three hundred free adult boll weevils and 100 adults enclosed in simulated pupal cells were marked 
Table 1. Effects of enhanced (typical of stripper-harvested cotton) and minimum (typical of picker-harvested cotton) seed cotton cleaning in the cotton gin on recovery of boll weevils in the cleaned seed cotton

\begin{tabular}{|c|c|c|c|c|c|c|c|c|c|}
\hline $\begin{array}{c}\text { Cleaning } \\
\text { level }\end{array}$ & Rep & $\begin{array}{c}\text { Weevils } \\
\text { introduced }\end{array}$ & $\begin{array}{c}\text { Weevils } \\
\text { lost in } \\
\text { conveyance }\end{array}$ & $\begin{array}{c}\text { Recovered } \\
\text { in rock } \\
\text { trap }\end{array}$ & $\begin{array}{l}\text { Net into } \\
\text { cleaning } \\
\text { system }\end{array}$ & $\begin{array}{l}\text { Total weight of } \\
\text { cleaned seed } \\
\text { cotton }(\mathrm{kg})\end{array}$ & $\begin{array}{c}\text { Weight of } \\
\text { subsample } \\
(\mathrm{kg})\end{array}$ & $\begin{array}{l}\text { Expected } \\
\text { recovery }\end{array}$ & $\begin{array}{l}\text { Weevils } \\
\text { recovered } \\
\text { alive }\end{array}$ \\
\hline \multirow[t]{6}{*}{ Enhanced } & 1 & 1,000 & 4 & 2 & 994 & 36.23 & 11.13 & 305 & 0 \\
\hline & 2 & 1,000 & 6 & 1 & 993 & 34.91 & 10.51 & 299 & 0 \\
\hline & 3 & 1,000 & 5 & 0 & 995 & 34.96 & 10.18 & 290 & 0 \\
\hline & 4 & 1,000 & 7 & 0 & 993 & 32.41 & 10.02 & 307 & 0 \\
\hline & 5 & 1,000 & 4 & 1 & 995 & 33.01 & 10.09 & 304 & 0 \\
\hline & Total & 5,000 & 26 & 4 & 4,970 & 171.52 & 51.93 & 1,505 & 0 \\
\hline \multirow{7}{*}{ Minimum } & 1 & 1,000 & 8 & 0 & 992 & 30.89 & 12.73 & 409 & 0 \\
\hline & 2 & 1,000 & 4 & 0 & 996 & 32.25 & 10.35 & 320 & 0 \\
\hline & 3 & 1,000 & 1 & 0 & 999 & 33.18 & 10.72 & 323 & 0 \\
\hline & 4 & 1,000 & 9 & 3 & 988 & 34.51 & 10.16 & 291 & 0 \\
\hline & 5 & 1,000 & 2 & 1 & 997 & 33.83 & 10.17 & 300 & 0 \\
\hline & Total & 5,000 & 24 & 4 & 4,972 & 164.66 & 54.13 & 1,643 & 0 \\
\hline & Grand total & 10,000 & 50 & 8 & 9,942 & 336.18 & 106.06 & 3,148 & 0 \\
\hline
\end{tabular}

${ }^{a}$ Calculated based on the proportional weight of the cotton subsampled and assuming $100 \%$ survival of weevils entering the cleaning system.

with different colors of fluorescent powder and fed together into the laboratory's tower drying system at the suction telescope by using the methodology described above. All cleaning machinery was bypassed. Temperature treatments for one dryer included noheat added $\left(\approx 27^{\circ} \mathrm{C}\right), 66,107$, and $149^{\circ} \mathrm{C}$. In the experiments with two tower dryers, both were heated to the same mix-point temperature. In the case of two dryers, no survival was found in the $107^{\circ} \mathrm{C}$ treatment, so an $85^{\circ} \mathrm{C}$ treatment replaced that of $149^{\circ} \mathrm{C}$. All treatments were replicated three times. The cleaned seed cotton was collected at the gin stand feeder apron and subsampled for inspection under blacklights as described above. In all experiments, free boll weevils recovered alive were placed together in a petri dish containing a cotton wick soaked in water, held on a laboratory bench at room temperature, and examined after 2 and $24 \mathrm{~h}$ for continued survival. Boll weevils recovered alive in simulated pupal cells were returned to the cell and placed together in a petri dish (without water) and examined after 2 and $24 \mathrm{~h}$ for continued survival. Twenty marked free adults and twenty marked boll weevils in simulated pupal cells were kept similarly in petri dishes as controls for mortality.

Data Analysis. All experiments were replicated as described above, with the seed cotton cleaning experiments designed as randomized complete blocks. However, no surviving boll weevils were recovered in any of the cleaning-level or incline cleaner trials, precluding traditional analyses (see Results). The worth of the results lies in their relevance to what is basically a quarantine issue, namely, in providing information on the likelihood of boll weevil survival through the ginning process. We cannot conclude that because we obtained zero survivors in our set of experiments survival is not possible, because with a larger sample size a survivor might eventually be recovered (McArdle 1990, Venette et al. 2002). The question becomes one of placing a $95 \%$ upper confidence limit $\left(p_{u}\right)$ on the zeros observed based on the number of insects tested $(n)$. This limit is calculated based on the binomial distribution as follows: $p_{u}=1-(1-\mathrm{C})^{1 / n}$ (equation 1 ), where $\mathrm{C}$ is the desired confidence level (in this case 0.95) (Couey and Chew 1986, Venette et al. 2002). Because replications become meaningless when all survival results are zero, $n$ was based on data pooled over replications for a given treatment when calculating $p_{u}$.

The situation with the tower dryer experiments is different, because all insects have upper lethal temperature limits, and zero survival across all replicates at a given temperature is likely a true indication of inability to survive at that temperature. Percentage of survival data were arcsine square-root transformed and subjected to one-way analysis of variance (ANOVA). Within the one- or two-dryer treatments, significant differences $(\alpha=0.05)$ in mean percentage of survival between different temperatures were determined by Tukey's honestly significant difference (HSD) method (Keppel 1973). Differences in survival at a given temperature between the one- or two-dryer treatments were evaluated by a $t$-test. Means are presented \pm SE. All statistical analyses were performed with Statistix software (Analytical Software 2000).

\section{Results}

Boll Weevil Survival through Minimum and Enhanced Seed Cotton Cleaning Processes. A total of 50 boll weevils ( $5 \pm 0.8$ per replication) of the original 10,000 introduced fell from the conveyor belt or lodged in the corners of the bin and thus did not enter the cleaning system (lost in conveyance, Table 1). These weevils were subtracted from the total introduced when calculating the number of boll weevils expected in the subsamples of cleaned seed cotton if there was $100 \%$ survival and no removal with the trash. A small amount of waste was removed by the greenboll and rock trap and consisted of dry unopened bolls, pebbles, small dirt clods, a few locks of cotton, and small pieces of trash. Eight live boll weevils $(0.8 \pm 0.33$ per replication) were found in this waste (Table 1 ). These weevils also were subtracted from the total introduced when calculating expected recovery in the subsamples. 
Table 2. Effects of enhanced (typical of stripper-harvested cotton) and minimum (typical of picker-harvested cotton) seed cotton cleaning in the cotton gin on recovery of boll weevils in gelatin capsules in the cleaned seed cotton

\begin{tabular}{|c|c|c|c|c|c|c|c|c|c|c|}
\hline \multirow[t]{2}{*}{$\begin{array}{c}\text { Cleaning } \\
\text { level }\end{array}$} & \multirow[t]{2}{*}{ Rep } & \multirow[t]{2}{*}{$\begin{array}{c}\text { Net capsules } \\
\text { into } \\
\text { cleaning } \\
\text { system }\end{array}$} & \multirow[t]{2}{*}{$\begin{array}{c}\text { Total weight } \\
\text { of cleaned } \\
\text { seed cotton } \\
(\mathrm{kg})\end{array}$} & \multirow[t]{2}{*}{$\begin{array}{l}\text { Weight of } \\
\text { subsample } \\
(\mathrm{kg})\end{array}$} & \multirow[t]{2}{*}{$\begin{array}{l}\text { Expected } \\
\text { recovery }^{a}\end{array}$} & \multicolumn{2}{|c|}{$\begin{array}{c}\text { Recovered } \\
\text { adults } \\
\text { expelled from } \\
\text { capsules } \\
\end{array}$} & \multirow[t]{2}{*}{$\begin{array}{c}\text { Intact } \\
\text { cases } \\
\text { recovered }\end{array}$} & \multirow[t]{2}{*}{$\begin{array}{c}\text { Partial } \\
\text { cases } \\
\text { recovered }\end{array}$} & \multirow[t]{2}{*}{$p_{u}$ alive $^{b}$} \\
\hline & & & & & & Alive & Dead & & & \\
\hline \multirow[t]{4}{*}{ Enhanced } & 1 & 100 & 37.7 & 10.74 & 29 & 0 & 1 & 0 & 1 & \\
\hline & 2 & 100 & 38.6 & 10.78 & 28 & 0 & 0 & 0 & 0 & \\
\hline & 3 & 100 & 37.2 & 10.32 & 28 & 0 & 0 & 0 & 0 & \\
\hline & Total & 300 & 113.5 & 31.84 & 85 & 0 & 1 & 0 & 1 & 0.0350 \\
\hline \multirow[t]{5}{*}{ Minimum } & 1 & 100 & 37.7 & 10.64 & 28 & 0 & 0 & 0 & 0 & \\
\hline & 2 & 100 & 38.1 & 10.53 & 28 & 0 & 1 & 0 & 1 & \\
\hline & 3 & 100 & 38.1 & 10.47 & 27 & 0 & 1 & 0 & 0 & \\
\hline & Total & 300 & 113.9 & 31.64 & 83 & 0 & 2 & 0 & 1 & 0.0354 \\
\hline & Grand total & 600 & 227.4 & 63.48 & 167 & 0 & 3 & 0 & 2 & 0.0178 \\
\hline
\end{tabular}

${ }^{a}$ Calculated based on the proportional weight of the cotton subsampled and assuming $100 \%$ survival of weevils entering the cleaning system.

${ }^{b}$ Upper confidence limit $(95 \%)$ for zero recovery of live adults $\left(p_{u}\right)$ calculated from $p_{u}=1-(1-\mathrm{C})^{1 / n}$, by using expected recovery as

Neither live boll weevils nor intact dead boll weevils were detected in any of the subsamples of cleaned seed cotton for either the enhanced or minimum levels of cleaning (Table 1). Some boll weevil parts were found, but all boll weevils seemed to have been either completely broken up by the cleaning machinery or removed from the seed cotton along with the trash. The upper $95 \%$ confidence limit $\left(p_{u}\right)$ for the enhanced and minimum treatments were calculated using equation 1 , where $n$ is the total number of boll weevils expected to be recovered for each treatment (Table $1)$. For the minimum level of cleaning, $p_{u}=1-$ $(0.05)^{1 / 1643}=0.00182$. Thus, we are $95 \%$ certain that the survival rate lies between 0 and 182 boll weevils per 100,000 entering the minimum cleaning system, or between 0 and $0.182 \%$. Because the enhanced cleaning level includes the same machinery as the minimum level with the addition of a combination bur and stick machine, the grand total of boll weevils expected to be recovered can be used for $n$ (Table 1). Thus, for the enhanced cleaning system, $p_{u}=1-(0.05)^{1 / 3148}=$ 0.00095 , and we can be $95 \%$ certain that the survival rate lies between 0 and 95 boll weevils per 100,000 introduced, or between 0 and $0.095 \%$.

No live encapsulated boll weevils were recovered in the rock trap or in the cleaned seed cotton for either level of cleaning (Table 2). One empty partial capsule was found in the seed cotton for each cleaning level. A total of one and two dead, severely mutilated adults, which had been expelled from their capsules, were recovered in the cleaned seed cotton after enhanced and minimum cleaning, respectively. Because of the small sample sizes, the $95 \%$ upper confidence limits for the observed zero survival of encapsulated adults (Table 2) are much higher than for the free adults.

Boll Weevil Survival through Incline Cylinder Cleaners. No live adults, either free or encapsulated, were recovered in subsamples of seed cotton after passage through two incline cylinder cleaners (Table $3)$. The $p_{u}$ values indicate $95 \%$ confidence that the survival rates lie between 0 and 54 boll weevils per 10,000 free adults introduced $(0-0.54 \%)$, and between 0 and 270 boll weevils per 10,000 capsules introduced $(0-2.70 \%)$. A few dead boll weevils were recovered, and these weevils were invariably severely damaged. However, we did recover a total of 10 live free adults $(0.4 \%)$ and five live encapsulated adults (1.0\%) in the green-boll and rock trap.

Boll Weevil Survival through Tower Dryers. Observed air temperatures at the mix-point for both tower dryers were close to the target temperatures (Table 4). As expected, temperatures decreased as the

Table 3. Recovery of live and dead boll weevil adults, both free and encapsulated, in cleaned seed cotton after passage through two incline cylinder cleaners

\begin{tabular}{|c|c|c|c|c|c|c|c|c|}
\hline \multirow{3}{*}{ Rep } & \multicolumn{4}{|c|}{ Free adults } & \multicolumn{4}{|c|}{ Encapsulated adults } \\
\hline & \multirow{2}{*}{$\begin{array}{l}\text { Expected } \\
\text { recovery }\end{array}$} & \multicolumn{2}{|c|}{ Recovered } & \multirow{2}{*}{$p_{u}$ alive $^{b}$} & \multirow{2}{*}{$\begin{array}{l}\text { Expected } \\
\text { recovery }\end{array}$} & \multicolumn{2}{|c|}{ Recovered } & \multirow{2}{*}{$p_{u}$ alive $^{b}$} \\
\hline & & Alive & $\overline{\text { Dead }}$ & & & Alive & $\overline{\text { Dead }}$ & \\
\hline 1 & 108 & 0 & 0 & & 22 & 0 & 2 & \\
\hline 2 & 111 & 0 & 7 & & 22 & 0 & 0 & \\
\hline 3 & 110 & 0 & 6 & & 22 & 0 & 3 & \\
\hline 4 & 109 & 0 & 5 & & 22 & 0 & 0 & \\
\hline 5 & 111 & 0 & 2 & & 22 & 0 & 0 & \\
\hline Total & 549 & 0 & 20 & 0.0054 & 110 & 0 & 5 & 0.027 \\
\hline
\end{tabular}

${ }^{a}$ Calculated based on the proportional weight of the cotton subsampled and assuming $100 \%$ survival of weevils entering the incline cleaners.

${ }^{b}$ Upper confidence limit $(95 \%)$ for zero recovery of live adults $\left(p_{u}\right)$ calculated from $p_{u}=1-(1-\mathrm{C})^{1 / n}$, by using expected recovery as $n$. 
Table 4. Target mix-point temperature, and observed temperatures at the mix-point, tower dryer inlet, and tower dryer outlet during passage of boll weevils in seed cotton

\begin{tabular}{|c|c|c|c|c|c|c|c|}
\hline \multirow{2}{*}{ No. dryers } & \multirow{2}{*}{ Target temp } & \multirow{2}{*}{ Mix point 1} & \multicolumn{2}{|c|}{ Tower 1} & \multirow{2}{*}{ Mix point 2} & \multicolumn{2}{|c|}{ Tower 2} \\
\hline & & & in & out & & in & out \\
\hline \multirow[t]{4}{*}{ One } & No heat & 26 & & & & & \\
\hline & 66 & 64 & 53 & 52 & & & \\
\hline & 107 & 106 & 83 & 79 & & & \\
\hline & 149 & 149 & 114 & 113 & & & \\
\hline \multirow[t]{4}{*}{ Two } & No heat & $27 \pm 1.7$ & $25 \pm 1.9$ & $25 \pm 1.6$ & $27 \pm 1.7$ & $24 \pm 1.2$ & $24 \pm 1.0$ \\
\hline & 66 & $66 \pm 0.8$ & $59 \pm 1.2$ & $56 \pm 1.3$ & $68 \pm 0.9$ & $50 \pm 0.8$ & $49 \pm 0.5$ \\
\hline & 85 & $86 \pm 0.6$ & $77 \pm 0.2$ & $73 \pm 0.2$ & $86 \pm 0.5$ & $66 \pm 0.3$ & $65 \pm 0.3$ \\
\hline & 107 & $107 \pm 0.0$ & $91 \pm 2.0$ & $92 \pm 6.6$ & $108 \pm 1.0$ & $75.7 \pm 2.0$ & $74 \pm 1.7$ \\
\hline
\end{tabular}

For the one-dryer experiment, readings were taken only for the third of three replications. Data for two dryers represent means \pm SE of three replications.

heated air traveled to and through each dryer. The differential between the mix-point and the entrance to the dryer was consistently greater in the second tower $\left(18.7 \pm 3.14^{\circ} \mathrm{C}\right)$ than the first $\left(8.9 \pm 1.64^{\circ} \mathrm{C}\right)$ (mean difference, $9.7 \pm 1.68^{\circ} \mathrm{C}$; paired $t$-test, $t_{\mathrm{df}=11}=5.77$, $P=0.0001)$.

Recovery of marked boll weevils was consistently less than expected if none were removed with the trash (Table 5). The mean percentage of recovered weevils across all temperatures was significantly less after passage through two dryers than after passage through one dryer for both free (one dryer, $87.4 \%$; two dryers, $\left.76.8 \% ; t_{\mathrm{df}=22}=2.31, P=0.03\right)$ and encapsulated boll weevils (one dryer, $86.7 \%$; two dryers, $62.4 \%$; $\left.t_{\mathrm{df}=22}=2.92, P=0.008\right)$. Mortality of marked free adults in the controls was very low at $2 \mathrm{~h}$ but averaged $15.0 \pm 3.9$ and $5.8 \pm 1.49 \%$ for free and encapsulated control boll weevils, respectively, after $24 \mathrm{~h}$. Percentage of mortality among marked boll weevils recovered was corrected for mortality in the controls by using Abbott's formula (Abbott 1925) and converted to percentage of survivorship. This corrected percentage of survivorship was multiplied by the percentage of total recovery at each temperature to obtain corrected percentage of recovery of live boll weevils. The corrected percentage of recoveries of live boll weevils that survived 2 versus $24 \mathrm{~h}$ were very similar at all temperatures, so only the 2-h data are presented (Fig. 1).

Even without heat, passage through the dryers was a source of boll weevil elimination, both through removal with the trash and mortality (Table 5; Fig. 1).
Survival of free or encapsulated adults through one or two dryers at $66^{\circ} \mathrm{C}$ was not significantly different than when no heat was added. However, at temperatures tested above $66^{\circ} \mathrm{C}$, survival declined dramatically for free adults. No encapsulated boll weevils survived one dryer at $149^{\circ} \mathrm{C}$ or two dryers at $85^{\circ} \mathrm{C}$. A small percentage of free adults survived when passed through a single dryer at $107^{\circ} \mathrm{C}$, but none survived the $149^{\circ} \mathrm{C}$ treatment. Increased exposure to high temperatures induced higher mortality. No boll weevils survived after passing through two dryers at $85^{\circ} \mathrm{C}$, indicating that the critical temperature for complete mortality with two dryers lies between 66 and $85^{\circ} \mathrm{C}$.

\section{Discussion}

In its passage with the seed cotton to the gin stand, a boll weevil encounters severe mechanical and environmental conditions, including agitation and pressing by multiple spiked cylinders against grid-rod sections, wiping onto sawtoothed cylinders by stationary brushes, repeated slinging against stationary rods by centrifugal forces 25-50 times the force of gravity, striking the walls of conveyance piping at speeds up to $100 \mathrm{~km} / \mathrm{h}$, and exposure to temperatures as high as $176^{\circ} \mathrm{C}\left(350^{\circ} \mathrm{F}\right)$ (Baker et al. 1994a,b). In this study, we found no evidence that a boll weevil can survive passage through the minimal machinery sequence typically used to clean picker-harvested cotton, even when the dryers were unheated. Furthermore, we found no evidence that a boll weevil can survive pas-

Table 5. Recovery of free and encapsulated boll weevils (dead and alive combined) in $\approx 10$-kg subsamples of seed cotton passed through one or two tower dryers at the indicated temperatures

\begin{tabular}{|c|c|c|c|c|c|}
\hline \multirow{2}{*}{$\begin{array}{c}\text { No. } \\
\text { dryers }\end{array}$} & \multirow{2}{*}{$\begin{array}{c}\text { Temp } \\
\left({ }^{\circ} \mathrm{C}\right)\end{array}$} & \multicolumn{2}{|c|}{ Free adults } & \multicolumn{2}{|c|}{ Encapsulated adults } \\
\hline & & $\begin{array}{l}\text { Expected } \\
\text { recovery }\end{array}$ & $\begin{array}{c}\% \text { total } \\
\text { recovery }\end{array}$ & $\begin{array}{l}\text { Expected } \\
\text { recovery }\end{array}$ & $\begin{array}{l}\% \text { total } \\
\text { recovery }\end{array}$ \\
\hline \multirow[t]{4}{*}{ One } & 27 & 66.6 & $88.6 \pm 0.07$ & 22.2 & $64.6 \pm 0.09$ \\
\hline & 66 & 66.6 & $96.1 \pm 0.05$ & 22.2 & $96.1 \pm 0.05$ \\
\hline & 107 & 66.7 & $82.5 \pm 0.06$ & 22.2 & $87.0 \pm 0.13$ \\
\hline & 149 & 66.7 & $82.5 \pm 0.05$ & 22.2 & $99.0 \pm 0.21$ \\
\hline \multirow[t]{4}{*}{ Two } & 27 & 66.5 & $77.7 \pm 0.08$ & 22.2 & $64.7 \pm 0.02$ \\
\hline & 66 & 66.7 & $82.5 \pm 0.08$ & 22.2 & $81.0 \pm 0.05$ \\
\hline & 85 & 66.4 & $73.3 \pm 0.06$ & 22.1 & $55.7 \pm 0.11$ \\
\hline & 107 & 66.4 & $73.8 \pm 0.10$ & 22.1 & $48.2 \pm 0.04$ \\
\hline
\end{tabular}

\footnotetext{
${ }^{a}$ Calculated based on the proportional weight of the cotton subsampled and assuming $100 \%$ survival of weevils entering the dryers.
} 

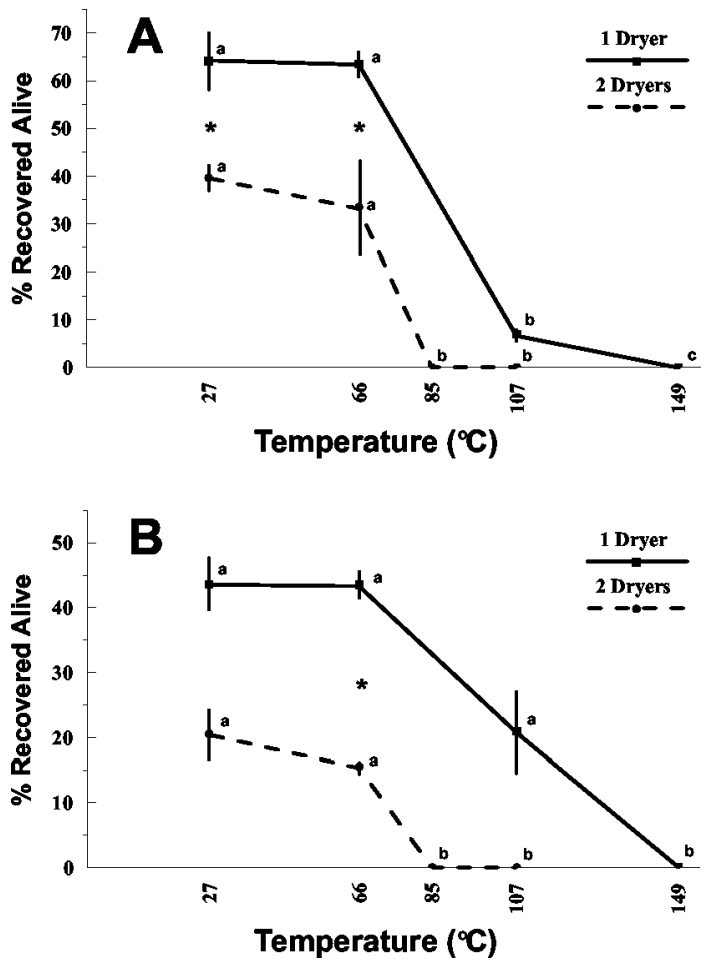

Fig. 1. Mean \pm SE percentage of (A) free adult or (B) encapsulated boll weevils recovered alive from $10-\mathrm{kg}$ of seed cotton subsamples after passage through one or two tower dryers in the gin at indicated mix-point temperatures (see Table 4 for actual dryer temperatures). Means along the same line followed by the same letter are not significantly different (Tukey HSD, $\alpha=0.05$ ). Means at the same temperature marked with an asterisk $(*)$ are significantly different $(t$-test, $\alpha=0.05)$.

sage through two incline cleaners, which constitute only a portion of the seed cotton cleaning process.

The potential for deposit of live boll weevils into a product beyond the gin stand can be calculated by multiplying the observed survival rates, or $p_{u}$ values in the case of zero recoveries, determined for each subprocess leading to that product. The upper 95\% CL $\left(p_{u}\right)$ placed on a zero recovery rate can be thought of as the worst-case estimate for potential survivability through a given ginning subprocess. Our experiments indicate that in the worst statistical case, one could expect 182 boll weevils of each 100,000 introduced to survive in the minimally cleaned seed cotton to approach the gin stand. In a survey of fields and modules in three boll weevil-infested areas of Texas, we found that on average $\approx 3,000$ boll weevils were packed alive into each cotton module (Sappington et al. 2004). For such a module, one would estimate a maximum of six boll weevils surviving to the gin stand. Mortality arising from passage through the gin stand and through subsequent subprocesses will be reported elsewhere (see Brashears et al. 2002 and Sappington et al. 2003 for preliminary data).

However, the $p_{u}$ estimates are based solely on sample size. Our observations strongly suggest that boll weevil survivability is much closer to zero than to the $p_{u}$, both for the seed cotton cleaning processes as a whole and for the incline cleaners alone. In both experiments, very few boll weevil parts were recovered in the cleaned seed cotton, and no intact boll weevils were recovered, suggesting that boll weevils not removed with the trash were mechanically obliterated. Similarly, the near lack of even partially intact gelatin capsules in the samples indicates that it is very unlikely that a pupal cell can make it through the cleaning system to approach the gin stand intact with a healthy boll weevil inside. In addition, heated dryers proved to be an important source of boll weevil mortality, especially when two were run at moderately high temperatures. At higher mix-point temperatures, $149^{\circ} \mathrm{C}$ for one tower and only $85^{\circ} \mathrm{C}$ for two towers, boll weevils cannot survive, and mortality caused by cleaning machinery becomes a moot point. Thus, we conclude that few if any boll weevils can survive the precleaning process to approach the gin stand in the seed cotton.

However, we did recover a number of live healthy boll weevils in the green boll/rock trap in both the seed cotton cleaning and the incline cylinder cleaner experiments, at an average rate of $\approx 0.12 \%$ for free adults and $0.45 \%$ for encapsulated adults. This may pose the greatest threat for boll weevil survival and escape from the gin. Thus, it is important that at-risk gins either expeditiously destroy the trash collected in the rock trap or collect it in a container that will not permit boll weevil escape. Another potential avenue of escape is with the gin trash, which is shunted out of the cleaning system at several points in the process. All gin trash beyond the green boll/rock trap passes through a trash fan, which is a source of high mortality in the pink bollworm, Pectinophora gossypiella (Saunders) (Robertson et al. 1959, Hughs and Staten 1995). The results of our studies on boll weevil survival through trash fans will be reported elsewhere.

\section{Acknowledgments}

We thank Latha Bommireddy, Veronica Cardoza, Jimmy Castro, Andy Cranmer, Valentina Greenberg, Lanthia Jones, Anand Sapkota, R. B. Shrestha, Bill Turner, and Orlando Zamora for technical assistance. We also thank Leeda Wood for efforts in keeping us supplied with large numbers of laboratory-reared boll weevils. Funding was provided in part by grants IPM01-023 to R.V.B. and T.W.S. and IPM02-004 to T.W.S. and A.D.B. from the Texas Department of Agriculture.

\section{References Cited}

Abbott, W. S. 1925. A method of computing the effectiveness of an insecticide. J. Econ. Entomol. 18: 265-267.

Analytical Software. 2000. Statistix for Windows, version 7.0: user's manual. Analytical Software, Tallahassee, FL.

Anthony, W. S. 1994. Overview of the ginning process, pp. 43-46. In W. S. Anthony and W. D. Mayfield [eds.], Cotton ginners handbook. U.S. Department of Agriculture, Agricultural Handbook 503.

Anthony, W. S., S. E. Hughs, and W. D. Mayfield. 1994. Ginning recommendations for processing machine- 
picked cotton, pp. 240-241. In W. S. Anthony and W. D Mayfield [eds.], Cotton ginners handbook. U.S. Department of Agriculture, Agricultural Handbook 503.

Baker, R. V. 1994. Ginning recommendations for processing machine-stripped cotton, pp. 242-243. In W. S. Anthony and W. D. Mayfield [eds.], Cotton ginners handbook. U.S. Department of Agriculture, Agricultural Handbook 503.

Baker, R. V., W. S. Anthony, and R. M. Sutton. 1994a. Seed cotton cleaning and extracting, pp. 69-90. In W. S. Anthony and W. D. Mayfield [eds.], Cotton ginners handbook. U.S. Department of Agriculture, Agricultural Handbook 503.

Baker, R. V., E. P. Columbus, R. C. Eckley, and B. J. Stanley. 1994b. Pneumatic and mechanical handling systems, pp. 143-171. In W. S. Anthony and W. D. Mayfield [eds.], Cotton ginners handbook. U.S. Department of Agriculture, Agricultural Handbook 503.

Brashears, A. D., R. V. Baker, T. W. Sappington, S. C. Carroll, M. D. Arnold, and M. N. Parajulee. 2002. Boll weevil survival in baled lint. In Proceeding of the Beltwide Cotton Conference (CD). National Cotton Council, Memphis, TN

Couey, H. M., and V. Chew. 1986. Confidence limits and sample size in quarantine research. J. Econ. Entomol. 79: 887-890.

Hughs, S. E., and R. T. Staten. 1995. Pink bollworm mortality using large-diameter gin-trash fans. Appl. Eng. Agric. 11: 281-284.

Hughs, S. E., G. J. Mangialardi, Jr., and S. G. Jackson. 1994. Moisture control, pp. 58-68. In W. S. Anthony and W. D. Mayfield [eds.], Cotton ginners handbook. U.S. Department of Agriculture, Agricultural Handbook 503.

Keppel, G. 1973. Design and analysis: a researcher's handbook. Prentice Hall, Englewood Cliffs, NJ.

Laird, J. W., B. M. Norman, S. Stuller, and P. Bodovsky. 1994. Seed cotton unloading systems, pp. 46-58. In W. S. Anthony and W. D. Mayfield [eds.], Cotton ginners hand- book. U.S. Department of Agriculture, Agricultural Handbook 503

McArdle, B. H. 1990. When are rare species not there? Oikos 57: 276-277.

Nelson, L., and N. Turner. 2003. Cotton moisture control in West Texas, pp. 742-745. In Proceedings of the Beltwide Cotton Conference, 6-10 January, Nashville, TN National Cotton Council, Memphis, TN.

Robertson, O. T., V. L. Stedronsky, and D. H. Currie. 1959 Kill of pink bollworms in the cotton gin and the oil mill. USDA-ARS Prod. Res. Rep. No. 26.

Sappington, T. W., A. D. Brashears, M. N. Parajulee, S. C. Carroll, M. D. Arnold, J. W. Norman, Jr., A. E. Knutson, and R. V. Baker. 2003. Modules, gins, and the threat of boll weevil introductions: what we know so far, pp. 1329 1339. In Proceedings of the Beltwide Cotton Conference, 6-10 January, Nashville, TN. National Cotton Council, Memphis, TN.

Sappington, T. W., A. D. Brashears, M. N. Parajulee, S. C. Carroll, M. D. Arnold, J. W. Norman, Jr., and A. E Knutson. 2004. Potential for transport of boll weevils (Coleoptera: Curculionidae) to the cotton gin within cotton modules. J. Econ. Entomol. (in press).

Siddaiah, M., M. A. Lieberman, and S. E. Hughs. 2002. Automation in cotton ginning. In Proceedings of the Beltwide Cotton Conference, 8-12 January, Atlanta, GA. National Cotton Council, Memphis, TN.

Venette, R. C., R. D. Moon, and W. D. Hutchinson. 2002. Strategies and statistics of sampling for rare individuals. Annu. Rev. Entomol. 47: 143-174.

Williams, M. R. 2003. Cotton insect loss estimates - 2002 , pp. 1217-1273. In Proceedings of the Beltwide Cotton Conference, 6-10 January, Nashville, TN. National Cotton Council, Memphis, TN.

Received 21 January 2004; accepted 10 April 2004. 